\title{
Perancangan dan Analisis Sistem Informasi Persediaan Barang pada CV UMA HANA
}

\author{
Ria Manurung \\ Sekolah Tinggi Ilmu Komputer Yos Sudarso Purwokerto \\ e-mail: ria.manurung74@gmail.com
}

Diajukan:18 Oktober 2019.; Direvisi: 28 November 2019; Diterima: 28 November 2019

\begin{abstract}
Abstrak
Perkembangan IPTEK yakni teknologi informasi yang sangat cepat tentu akan dapat mempermudah kegiatan bisnis. Akan tetapi, kegiatan bisnis pada UMA HANA meliputi pengelolaan pembelian, penjualan dan persediaan barang pada UMA HANA masih dilakukan dengan cara manual sehingga memungkinkan terjadi kesalahan. Oleh sebab itu dibutuhkan adanya sebuah sistem secara komputerisasi berbasis desktop yang diharapkan dapat membantu pencatatan transaksi pembelian, dan penjualan, serta persediaan barang sehingga mampu menyediakan informasi yang cepat, akuntabel dan akurat kepada user UMA HANA. Metode Development Life Cycle Software dengan metode waterfall dipergunakan untuk merancang sistem pada penelitian ini. Uji hipotesis dan uji manfaat digunakan untuk mencermati bagaimana dan sejauh mana pengaruh dan manfaat yang diberikan. Sistem UMA HANA juga berguna untuk mempermudah membuat laporan. Sistem ini mempunyai keunggulan dalam kegunaan, kemudahan untuk dipelajari, efisiensi dan akurasi.
\end{abstract}

Kata kunci: Persediaan Barang, Sistem, Informasi, Sistem Informasi.

The development of science and technology which is very fast information technology will certainly be able to facilitate business activities. However, business activities at UMA HANA include the management of purchases, sales and inventory of goods at UMA HANA is still done manually so that errors can occur. Therefore it is needed a desktop-based computerized system that is expected to help record the purchase and sale transactions, as well as inventory so that it can provide fast, accountable and accurate information to UMA HANA users. Development Life Cycle Software method with the waterfall method is used to design the system in this study. Hypothesis testing and benefit testing are used to examine how and to what extent the effects and benefits are given. The UMA HANA system is also useful for making reporting easier. This system has advantages in usability, ease of learning, efficiency and accuracy.

Keywords: Inventory, System, Information, Information System.

\section{Pendahuluan}

Dengan perkembangan IPTEK yakni teknologi informasi yang sangat cepat tentu akan mempengaruhi berbagai bidang aspek kehidupan, salah satunya adalah untuk pemrosesan data yang hasilnya tentu saja akan menjadi lebih cepat serta perhitungannya menjadi lebih akurat. Aplikasi berbasis desktop digunakan untuk membantu pengelolaan data seperti menyimpan dan memunculkan data dengan lebih cepat karena tidak tersambung koneksi internet. Aplikasi desktop telah dilakukan manusia untuk menyelesaikan tugas-tugas kesehariannya termasuk Sistem Informasi CV UMA HANA. CV UMA HANA merupakan salah satu agen perdagangan yang mengkhususkan untuk menjual produk-produk tas dan dompet buatan Taiwan. CV UMA HANA menjual produk-produk tas dan dompet melalui konter-konter yang terletak di pusat perbelanjaan di Indonesia yang terdapat di berbagai kota meliputi Jakarta di Mall Taman Anggrek, Yogyakarta di Ambarukmo Plaza, Semarang di Mall Ciputra, Purwokerto di MORO, dan beberapa kota lainnya. Selain itu, penjualan juga dilakukan secara online. Kantor pusat CV UMA HANA terletak di Perumahan Permata Hijau 2 No 50 Purwokerto, Jawa Tengah.

Kegiatan bisnis CV UMA HANA dilakukan masih dengan cara manual yakni meliputi pengelolaan pembelian, penjualan dan persediaan. Dengan data-data transaksi yang terdiri dari pembelian serta penjualan yang banyak maka akan memerlukan banyak waktu untuk memasukkan data-data transaksi tersebut. Selain itu pencatatan pembelian dan penjualan terpisah dari data-data transaksi yang dimasukkan 
karena tidak adanya integrasi antara data transaksi tersebut. Pencatatan persediaan barang untuk setiap barang yang akan dikirim ke konter-konter di setiap kota dicatat secara manual sehingga dapat terjadi kesalahan. Permasalahan lain yang timbul adalah kesulitan untuk mencari informasi tentang jumlah persediaan barang yang terdapat di konter dengan tepat yang mencakup masalah tentang pengurangan persediaan barang dengan dilakukannya penjualan. Beberapa peneliti sebelumnya dalam bidang IT telah membuat rancangan sistem untuk menjawab persoalan yang terjadi pada CV UMA HANA.

Berdasarkan permasalahan yang terdapat di Uma Hana, maka diperlukan adanya sebuah sistem untuk pengelolaan pembelian, penjualan dan persediaan secara komputerisasi berbasis desktop. Sistem ini diharapkan membantu pencatatan pembelian, penjualan dan persediaan barang, sehingga dapat memberikan informasi mengenai persediaan barang, data-data transaksi untuk pembelian maupun penjualan pada CV UMA HANA. Tujuan penelitian ini adalah mempermudah user untuk melakukan pencatatan persediaan barang dagangan, data-data transaksi untuk pembelian maupun penjualan barang agar cepat serta akurat pada CV UMA HANA.

\section{Metode Penelitian}

Metode dalam penelitian yang akan dipergunakan untuk melaksanakan penelitian berupa :

1. Wawancara

Wawancara ialah metode yang dilaksanakan untuk menghimpun data dengan cara berkomunikasi antara peneliti dan responden untuk mendapatkan informasi. Wawancara dilakukan kepada Management CV UMA HANA, Karyawan dan Mahasiswa STIKOM Yos Sudarso.

2. Observasi

Observasi yakni metode yang dilaksanakan peneliti untuk menghimpun data dengan cara peninjauan tempat secara langsung. Observasi langsung di kantor CV UMA HANA mengenai sistem yang sudah berjalan selama ini.

3. Survei

Survei yaitu metode yang dilaksanakan untuk menghimpun data dari responden sebagai sampel melalui kuesioner-kuesioner.

4. Kepustakaan

Kepustakaan yaitu pengumpulan data dengan metode mencari informasi dari buku, skripsi dan jurnal yang dibutuhkan untuk penelitian.

5. Metode Pengembangan Sistem

Software Development Life Cycle (SDLC) yaitu peralatan yang mendukung sistem Software Development Methodolgy. Tujuan dari pengembangan sistem SDLC untuk mengembangkan sistem informasi menjadi terstruktur sesuai dengan metode yang telah ditetapkan. Kelebihan Metode SDLC [1]:

a. Memiliki tahapan sebagai pedoman yang dipergunakan untuk pengembangan sistem.

b. Hasil sistem dapat menjadi lebih baik karena sebelum diimplementasikan, sistem dianalisis kemudian dirancang secara keseluruhan.

SDLC yang terdapat dalam buku karya [2] mendeskripsikan tahapan model "air terjun" yang dikenal sebagai istilah "the waterfall model". Menurut [2], model air terjun menyerupai alur atau siklus hidup dari peranti lunak dengan sekuensial atau berurut dimulai dari analisis, kemudian desain, lalu pengkodean dan dilanjutkan dengan pengujian. Berikut ini adalah ilustrasi model air terjun :

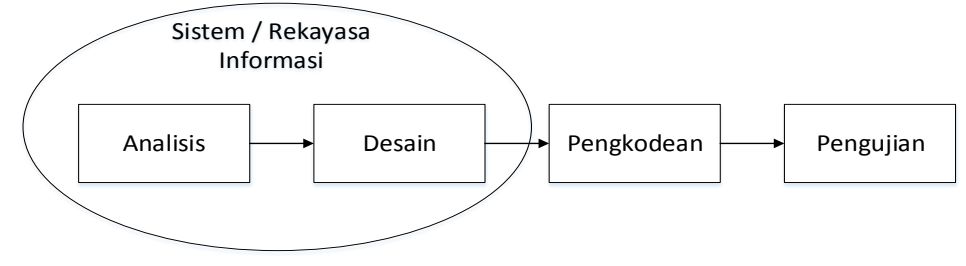

Gambar 1. Sistem model waterfall.

Perancangan dan Analisis Sistem Informasi Persediaan Barang pada CV UMA HANA (Ria Manurung) 
6. Pengujian

1) White-Box Testing

Melakukan uji kepada perangkat lunak terhadap desain maupun kode program apakah dapat menghasilkan masukan, keluaran dan fungsi-fungsi sesuai dengan keperluan spesifikasi.

2) Black-Box Testing

Melakukan uji terhadap spesifikasi fungsional perangkat lunak tanpa melakukan pengujian terhadap desain maupun kode program. Pengujian dilakukan untuk memahami apakah masukan, keluaran dan fungsi-fungsi dari peranti lunak tersebut sesuai dengan keperluan spesifikasi.

7. Responden

Penetapan sampel yang dipergunakan untuk penelitian ini yakni Simple Random Sampling Method di mana populasi mendapatkan kesempatan yang serupa ketika diambil sebagai sampel. Metode ini juga bisa dipakai dalam kondisi sebagai berikut [3]:

a. Populasi relatif kecil

b. Populasi bersifat homogen di mana anggota populasi mempunyai karakteristik yang hampir mirip satu sama lain

Pada penetapan responden penelitian ini tidak hanya melibatkan pemilik dan karyawan UMA Hana saja, melainkan melibatkan mahasiswa STIKOM Yos Sudarso sebagai responden. Penetapan responden pada mahasiswa STIKOM Yos Sudarso Purwokerto adalah sebagai penilai dari fungsi serta desain sistem yang dibangun.

Perhitungan ukuran sampel menggunakan rumus [4] :

$$
n=N /\left(1+N(e)^{2}\right)
$$

Dengan ketentuan:

$n=$ ukuran sampel

$\mathrm{N}=$ populasi

$\mathrm{e}=$ tingkat ketepatan

Dengan rumus tersebut, dapat dihitung ukuran sampel dari populasi sebanyak 64 dengan perincian pemilik UMA HANA sebanyak 1 dan karyawan UMA HANA sebanyak 1, mahasiswa S1 STIKOM Yos Sudarso angkatan 2014 sebanyak 29 dan mahasiswa S1 STIKOM Yos Sudarso angkatan 2015 sebanyak 33 dengan menentukan tingkat ketepatan 10\%:

$$
\begin{aligned}
n & =\mathrm{N} /\left(1+\mathrm{N}(\mathrm{e})^{2}\right) \\
& =64 /\left(1+64(0.10)^{2}\right) \\
& =60 / 1,64 \\
& =39,024 \\
& =39
\end{aligned}
$$

\begin{tabular}{|c|c|c|}
\hline No. & Nama & Jumlah \\
\hline 1 & Mahasiswa STIKOM Yos Sudarso Purwokerto & 37 \\
\hline 2 & Pemilik UMA HANA & 1 \\
\hline 3 & Karyawan UMA HANA & 1 \\
\hline
\end{tabular}

Jumlah sampel responden sebanyak 39 (tiga puluh sembilan). Pemilihan responden dilakukan dengan cara yaitu pemilik UMA HANA sebanyak 1 (satu) dan karyawan UMA HANA sebanyak 1 (satu), dan mahasiswa STIKOM Yos Sudarso sebanyak 37 (tiga puluh tujuh), seperti diuraikan berikut ini:

Tabel 1. Responden.

\subsection{Metodologi Pengembangan Sistem}

a. Diagram Konteks

Pada tahap ini, Sistem Informasi pada CV UMA HANA dapat digambarkan secara umum perihal keseluruhan dari sistem yang akan dibuat. Pada sistem terdapat dua entitas yaitu "Karyawan" dan "Pemilik. Di mana entitas "Karyawan" bisa melaksanakan proses Input Persediaan Barang, Input Data Pembelian, dan Input Data Pengiriman Barang Ke Konter serta meng-input Data Penjualan ke dalam sistem dan entitas 
"Pemilik" memperoleh proses Laporan Persediaan Barang, Laporan Data Pembelian, dan Laporan Data Pengiriman Barang Ke Konter, serta Laporan Data Penjualan dari sistem.

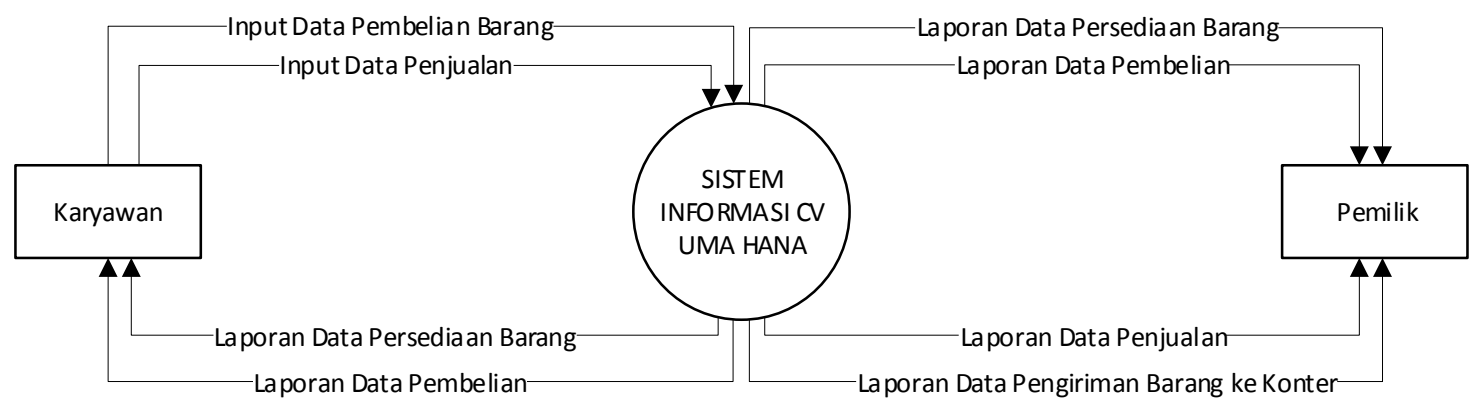

Gambar 2. Diagram konteks.

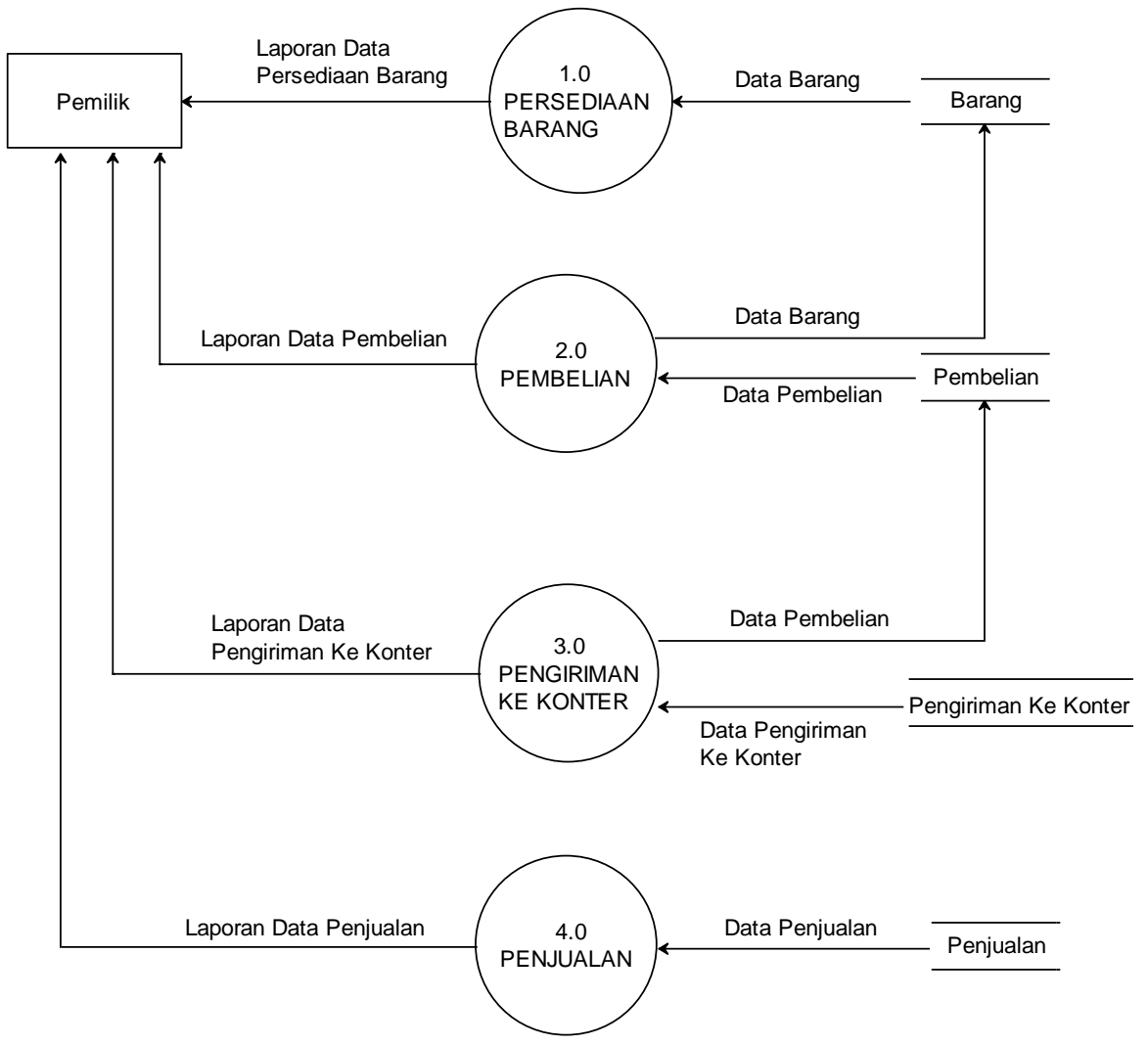

Gambar 3. Proses kegiatan pemilik. 


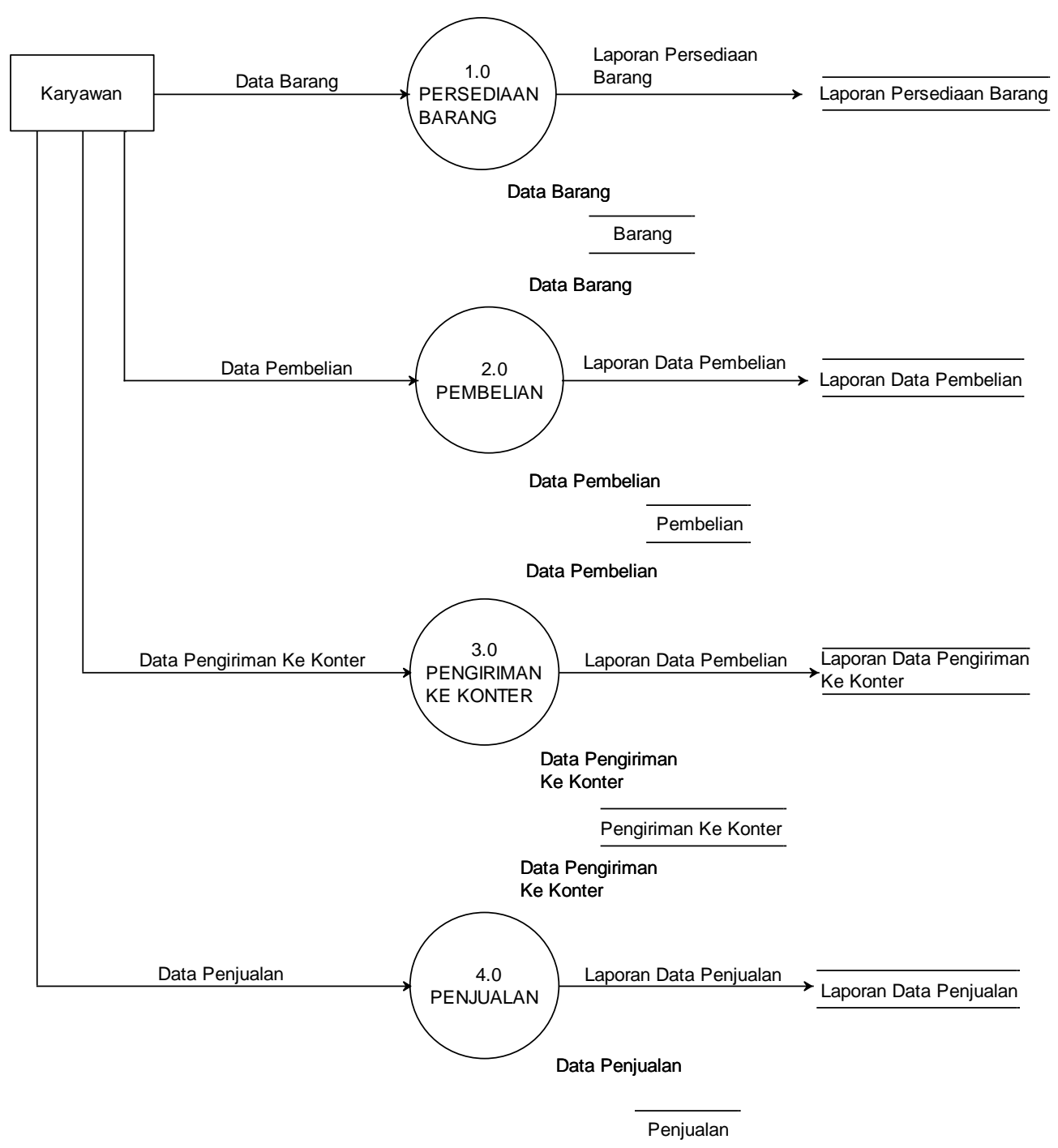

Gambar 4. Proses kegiatan karyawan.

\section{Hasil dan Pembahasan}

\subsection{Entity Relationship Diagram (ERD)}

Model ERD yaitu model pengembangan data yang dipergunakan dalam mendeskripsikan hubungan antara data yang terdapat pada basis data terhadap user secara terstruktur [5]. ERM diilustrasikan dalam bentuk diagram yang dikenal dengan diagram ERD seperti di bawah ini. 


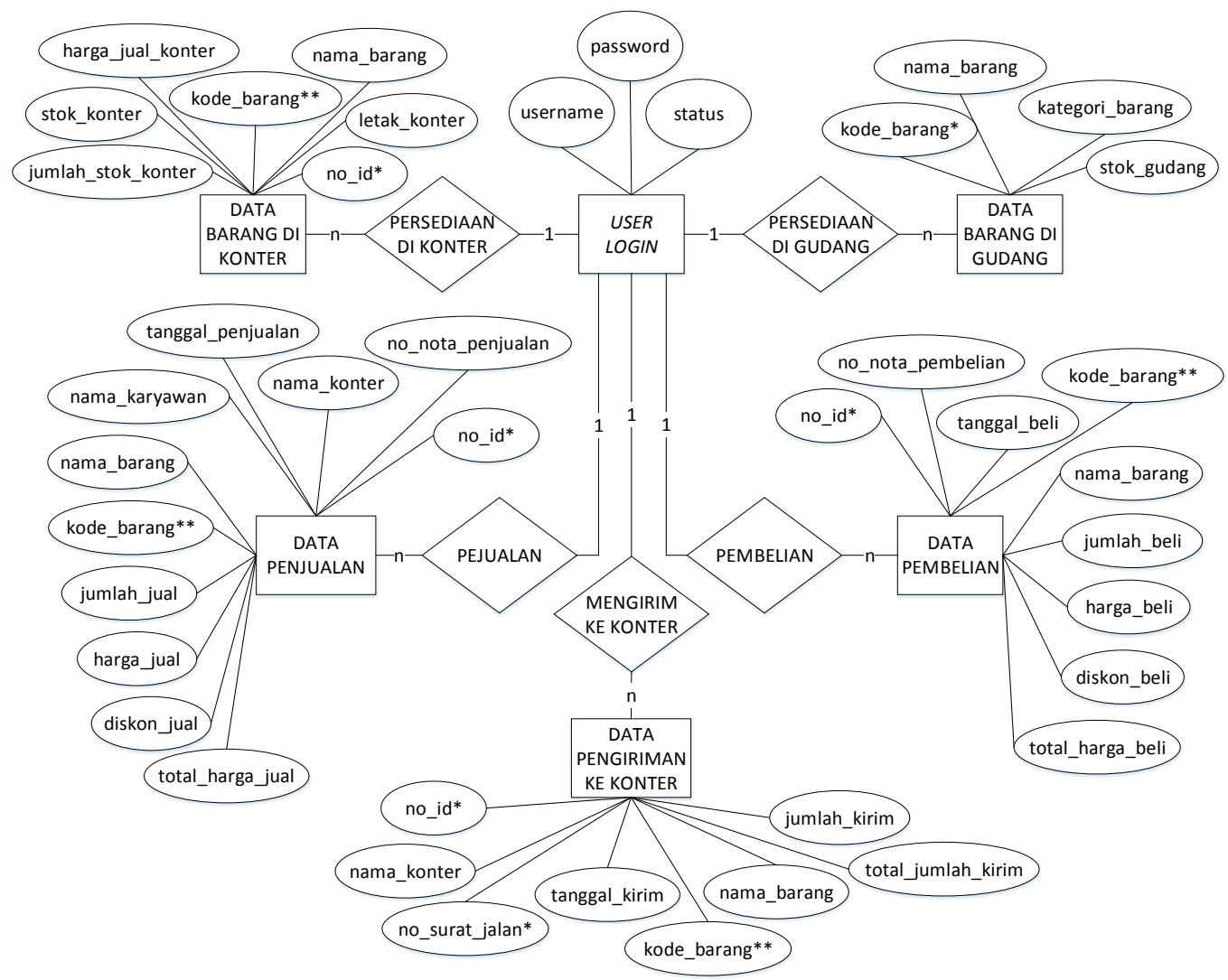

Gambar 5. Entity Relationship Diagram.

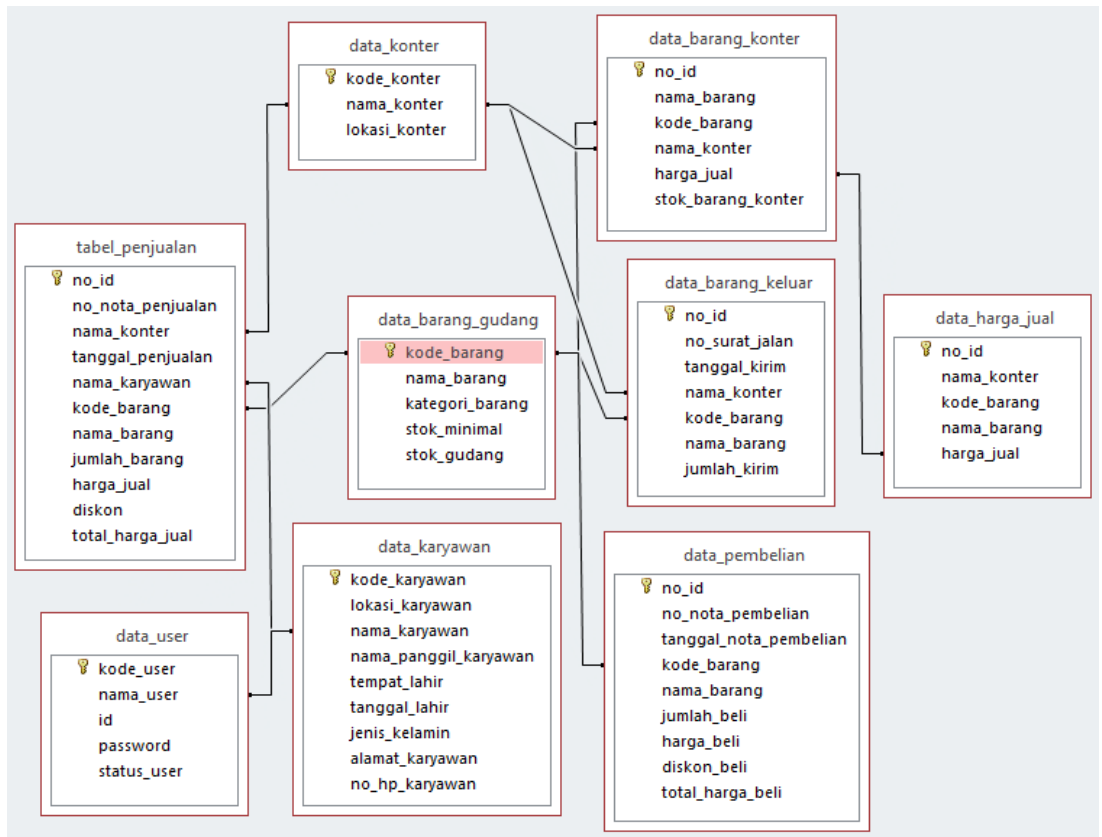

Gambar 6. Tabel relasi.

Tabel 2. Data penjualan.

\begin{tabular}{|c|c|c|c|}
\hline No & Nama field & Tipe Data & Panjang \\
\hline 1 & no_id* & varchar & 15 \\
\hline 2 & no_nota_penjualan & varchar & 20 \\
\hline 3 & nama_konter & varchar & 50 \\
\hline
\end{tabular}




\begin{tabular}{clcc}
\hline No & \multicolumn{1}{c}{ Nama field } & Tipe Data & Panjang \\
\hline 4 & tanggal_penjualan & date & \\
\hline 5 & nama_karyawan & varchar & 50 \\
\hline 6 & kode_barang & varchar & 20 \\
\hline 7 & nama_barang & varchar & 100 \\
\hline 8 & jumlah_barang & int & 5 \\
\hline 9 & harga_jual & int & 10 \\
\hline 10 & diskon & int & 10 \\
\hline 11 & total_harga_jual & int & 15 \\
\hline
\end{tabular}

\subsection{Menentukan Hipotesis}

Hipotesis penelitian ini yaitu:

1) Hipotesis $\mathrm{HO}$ yaitu mengungkapkan bahwa tidak terdapat perbedaan waktu secara nyata dalam pencarian informasi persediaan sebelum dan sesudah menggunakan sistem.

2) Hipotesis H1 yaitu mengungkapkan bahwa ada perbedaan waktu dalam pencarian informasi persediaan sebelum dan sesudah menggunakan sistem.

a. Uji Normalitas

Uji normalitas pada data menggunakan chi-square. Uji chi-square dipergunakan untuk menguji ketidaktergantungan dan homogenitas [6]. Uji normalitas dipergunakan untuk memahami apakah kumpulan data antara satu dan data lainnya bisa secara keseluruhan menghasilkan suatu sistem informasi.

b. Uji Hipotesis

Paried Samples t-Test dilakukan untuk membandingkan waktu dalam pencarian informasi persediaan. Langkah-langkah untuk menguji Paried Samples t-Test pada SPSS adalah melalui tahap Analyze, Compare Means dan Paired-Samples T Test yang dibandingkan ke Paried Variables, lalu pilih option pada Exelude Cases Analysis By Analysis dengan Confodence Interval $95 \%$.

\subsection{Interpretasi Hasil}

Hasil dari tabel Paried Samples t-Test yang didapatkan akan ditentukan keputusan untuk menyatakan bahwa $\mathrm{H} 0$ diterima atau $\mathrm{H} 0$ ditolak. Pengujian yang dibuat dengan memakai pengujian dua sisi di mana tingkat signifikan (a) $=5 \%$ atau 0,05 . Apabila (a) $<5 \%$ maka $\mathrm{H} 0$ ditolak, jika (a) $>5 \%$ maka H0 diterima.

\subsubsection{Uji Manfaat}

Dilakukan agar bisa menilai kegunaan dari sistem yang dibangun dan apakah bisa memberi manfaat bagi user. Metode survei dilakukan untuk menganalisis uji manfaat sehingga bisa diketahui apakah sistem dapat digunakan sesuai dengan ruang lingkup sistem yang sudah ditetapkan. Persiapan dilakukan dengan menyediakan Kuesioner. Kuesioner yaitu alat pendukung yang dipergunakan untuk melakukan metode survei. Variabel-variabel yang digunakan untuk membuat kuesioner adalah Usability (kegunaan), Efficiency (efisiensi), Learnability (mudah dipelajari) dan Acceptability (dapat diterima). Hasil dari responden dikategorikan dari skala 1 - sampai 4 (angka 1 dikategorikan dengan STS = Sangat Tidak Setuju, angka 2 dengan TS = Tidak Setuju, angka 3 dikategorikan dengan $\mathrm{S}=$ Setuju dan angka 4 dilambangkan sebagai SS = Sangat Setuju.

\subsubsection{Uji Validitas maupun Reliabilitas}

\section{1) Uji Validitas}

Dilakukan untuk mengukur ketepatan suatu item dalam kuesioner dengan melihat item-item pada kuesioner tersebut sudah tepat untuk melakukan pengukuran terhadap komponen yang butuh diukur. Uji validitas yang digunakan adalah uji validitas item. Validitas item diketahui dengan dimilikinya hubungan korelasi atau bantuan terhadap item total. Penilaian terhadap koefisien korelasi dilakukan secara langsung dengan memakai syarat minimal korelasi 0.30 . Jika korelasi di atas 0.30 maka pertanyaan-pertanyaan yang terdapat dalam kuesioner akan dinyatakan valid namun bila korelasi di bawah 0.30 maka dapat dinyatakan tidak valid. Tahapan melakukan uji validitas pada SPSS mesti melalui tahap Analyze, Correlate dan Bivariate serta memasukkan seluruh komponen maupun masukan ke kotak variabel.

2) Uji Reliabilitas

Uji reliabilitas dipergunakan untuk memahami konsistensi alat pengukuran, apakah alat pengukuran yang diinginkan dapat dimanfaatkan dan memiliki konsistensi bila pengukuran tersebut dilakukan secara berulang-ulang. Metode Cronbach's Alpha dilakukan untuk pengujian reliabilitas yang 
sesuai dengan penelitian ini yakni menggunakan skor berbentuk skala. Koefisien reliabilitas dapat diterima jika sama dengan 0,70 atau lebih dari 0,70. Langkah-langkah untuk uji reliabilitas pada SPSS melalui tahap Analyze, Scale dan Reliability Analysis dengan memasukkan ke kotak Items apabila item tidak gugur dan mengeluarkan item yang gugur untuk semua item yang sudah berada di kotak Items, selanjutnya melalui Statistics yaitu pada kotak Descriptives for pilih Scale if item deleted.

\subsection{Implementasi Sistem}

1. Tampilan Form pada Menu Utama

Dibuat untuk aplikasi yang dapat menampilkan keseluruhan fasilitas yang terdapat pada sistem yang bisa ditampilkan dalam Gambar 7 berikut:

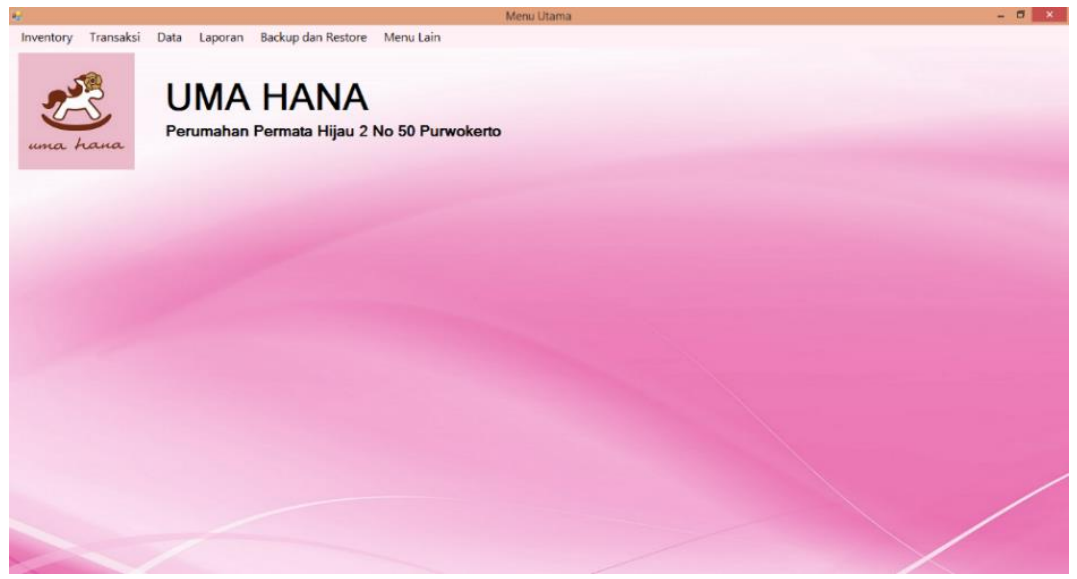

Gambar 7. Tampilan Form Menu Utama.

\section{Form Input Data Pembelian}

Tampilan Form Input Data Pembelian ini dibuat untuk aplikasi yang berfungsi untuk menyimpan data pembelian. Pada Form ini terdapat textbox "No Nota", "Kode Barang", "Nama Barang", "Jumlah Barang", "Harga Beli" dan "Total Harga" serta datetimepicker "Tanggal Pembelian". Pada Form ini memiliki beberapa fungsi button sebagai berikut :

a. Button Tambah

Button Tambah berfungsi untuk menambah data pembelian dimana isi dari textbox "No Nota" dan datetimepicker "Tanggal Pembelian" tidak dapat diubah.

b. Button Simpan

Button Simpan memiliki manfaat untuk menyimpan data pembelian.

c. Button Refresh

Button Refresh memiliki manfaat untuk memuat kembali data pembelian.

d. Button Keluar

Button Keluar memiliki manfaat untuk keluar dari Form Input Data Pembelian.

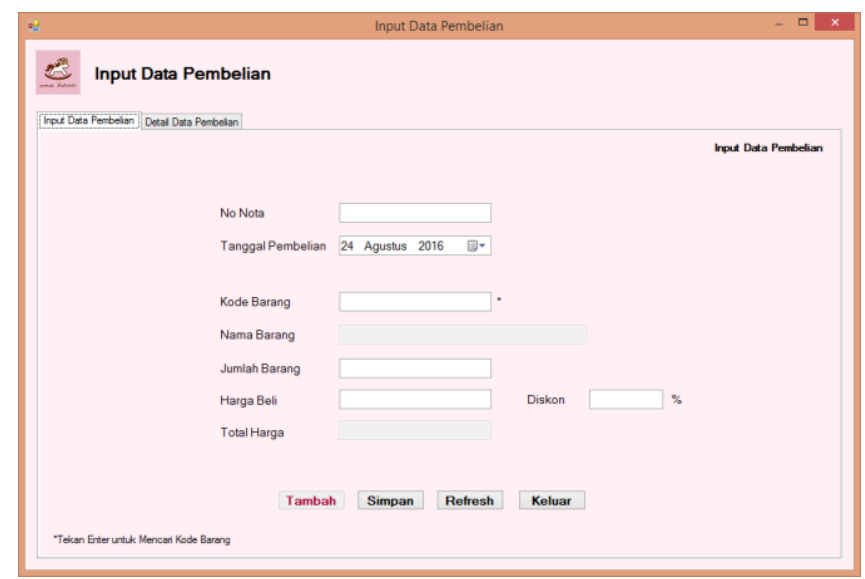

Gambar 8. Tampilan Form Input Data Pembelian.

Perancangan dan Analisis Sistem Informasi Persediaan Barang pada CV UMA HANA (Ria Manurung) 


\section{Form Input Data Pengiriman Barang Ke Konter}

Berikut ini adalah tampilan Form Input Data Pengiriman Barang ke Konter yang dibuat untuk sistem yang memiliki manfaat menyimpan data pengiriman barang ke konter. Pada Form ini terdapat textbox "No Surat Jalan", "Kode Barang", "Nama Barang", dan "Jumlah Barang" serta combobox "Nama Konter" dan datetimepicker "Tanggal” seperti ditampilkan pada Gambar 9 berikut ini:

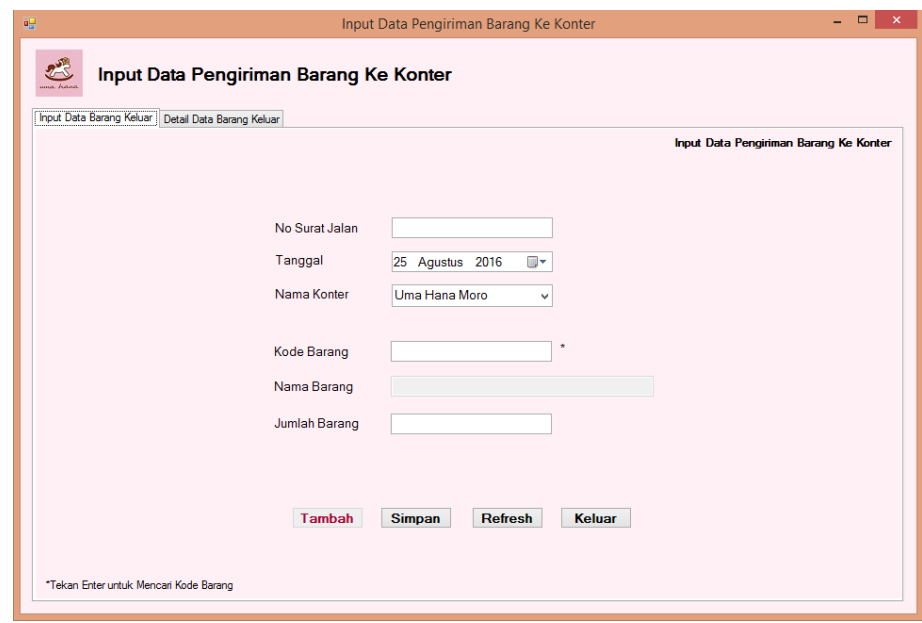

Gambar 9. Tampilan Form Input Data Pengiriman Barang ke Konter.

\section{Kesimpulan}

Dari hasil rancang aplikasi yang telah dilaksanakan kemudian dilakukan pengujian hipotesis dan uji manfaat terhadap produk ini maka diperoleh hasil dengan

1. H1 diterima yakni adanya perbedaan waktu yang signifikan dalam pencarian informasi persediaan sebelum dan sesudah menggunakan Sistem Informasi Pengelolaan Persediaan pada CV Pada UMA HANA.

2. Hasil dari pengujian hipotesis dengan parameter waktu yang menghasilkan mean waktu sebelum menggunakan sistem sebesar 12.3176 menit dan mean waktu sesudah menggunakan sistem sebesar 7.5705 menit.

3. Hasil dari uji manfaat yang diperoleh nilai persentase kegunaan sebesar $82,75 \%$, mudah dipelajari sebesar $83 \%$, efisiensi sebesar 80,5\% dan dapat diterima 77,5\%.

4. Sistem Informasi Pengelolaan Persediaan pada CV UMA HANA Purwokerto sangat berguna, mudah dipelajari untuk memberikan informasi mengenai persediaan barang, data-data transaksi pembelian dan penjualan serta untuk proses pembuatan laporan.

\section{Daftar Pustaka}

[1] R. \&. Shalahuddin, Rekayasa Perangkat Lunak Terstruktur dan Berorientasi Objek, Bandung: Informatika, 2016.

[2] R. Tantra, Manajemen Proyek Sistem Informasi, Yogyakarta: ANDI, 2016.

[3] Eriyanto, Teknik Sampling Analisis Opini Publik, Yogyakarta: LKIS, 2017.

[4] J. Sarwono, Prosedur-Prosedur Analisis Populer Aplikasi Riset Skripsi dan Tesis dengan Eviews, Yogyakarta: Gava Media, 2016.

[5] E. Sutanta, Basis Data Dalam Tinjauan Konseptual, Yogyakarta: ANDI, 2016.

[6] W. KOMPUTER, Panduan Aplikatif \& Solusi (PAS): Mengolah Data Statistik Hasil Penelitian dengan SPSS 17, Yogyakarta: ANDI, 2016. 